\title{
Science favoured by German coalition
}

German scientists have little to worry about in the recent coalition agreement of their government, which is planning few changes in research strategy and a lot more money. Budgets in education and research are set to almost double over the four-year legislative period.

The major coalition partner is the centreright alliance between the Christian Democratic Union and the Christian Social Party; the junior partner is the business-friendly Free Democratic Party. Annette Schavan (Christian Democrats) remains in charge of the ministry of research and education, and Thomas Rachel is likely to remain her deputy for research.

The generous funding agreements for universities and research agreed by the previous government last June will be maintained. So the budgets of major research organizations, including the Max Planck Society and the DFG, Germany's main research granting agency, will rise by $5 \%$ a year until 2015. Universities will receive a €5-billion (US\$7.4-billion) supplement between 2011 and 2015 to improve teaching and research.

The Excellence Initiative, a competition between universities to win 'elite' status, keeps the $€ 2.7$ billion promised for the period 2012-17. The four-year, €14.6-billion 'high-tech' programme that promoted applications in areas such as energy, climate, health and security and that would have expired this year - will be extended and expanded.

The agreement also promises special attention to materials research, and new legislation to give research institutions more control over their budgets.

There is less clarity in two sensitive research areas. The agreement stresses that green biotechnology is valuable for the national economy, but dodges specific mention of field trials of genetically modified crops which, although legal, have become nearly impossible to carry out owing to public resistance.

The agreement similarly acknowledges the 'opportunities for health' of stem-cell research, but does not tackle the thorny issue of the restrictive German laws on human embryonic stem-cell research. Instead, it says it will consider establishing a national 'dialogue platform' for more public discussions. The Free Democrats have withdrawn from their pre-election lobbying to further relax rules limiting the cell lines that German researchers may use.

"Relaxing rules to match those of some other big players in Europe, such as Switzerland, would make things a lot easier for us because we collaborate so much with European partners," says Oliver Brüstle, a stem-cell researcher at the University of Bonn.

"We are mostly satisfied, particularly by the increases in budget," says Jörg Hacker, head of the Berlin-based Robert Koch Institute and president-elect of the Leopoldina, Germany's national academy. "We hope that it will all work out as the coalition agreement plans."

Alison Abbott 